\title{
The Use of Acting Methodology in Singing Education: Michael Chekhov System*
}

\author{
Salim SEVER ${ }^{* *}$
}

\begin{abstract}
In this research, three main questions regarding the use of acting methodology in singing education were answered: (1) the general approach to voice education in our country, (2) the experiences and ideas of professional opera singers regarding the acting part of opera, and (3) the ideas of the experts who are currently working as professional singers and voice teachers regarding their area and regarding teaching how to act on the stage as a part of the voice instruction. The main theoretical instruction in acting on the stage is the methodology that has been created by Michael Chekhov. The findings of the study were also compared with the methodology by Chekhov. Based on the results, his methodology could be the theoritical basis for acting training in voice education.
\end{abstract}

Keywords: Singing, Acting, Michael Chekhov

\footnotetext{
This article is based on the $\mathrm{PhD}$ dissertation named "The use of acting methodology in singing education" undertaken in the supervision of Feridun Büyükaksoy.

** Lecturer, PhD. Ankara University Faculty of Educational Sciences, Department of Elementary Education. E-mail: salimsvr@gmail.com
} 


\section{SUMMARY}

Purpose: The purpose of this study was to find out the level of the use of acting methodology in the education of singers at music schools in the undergraduate level. Three main research questions on the use of acting methodology in voice education directed the study: (1) the general approach to voice education in our country, (2) the experiences and ideas of professional opera singers regarding the acting part of opera and (3) the ideas of the experts who are currently working as professional singers and voice teachers regarding their area and regarding teaching how to act on the stage as a part of voice instruction.

Method: Qualitative / descriptive research design was used as at the model. Data was collected via semi-structured interviews that were recorded. The records were transcribed on the paper later. The obtained data was evaluated via desciptive and content analysis.

Results: Based on the answers by the participants on the general approach to voice education in our country, the following results were found: Although a systematic voice-instruction approach has been used in in the departments of music education and in the conservatories, no instruction in acting has been given to the students in the departments of music education. The instruction in acting for the students at the conservatories is not systematic and the level of teaching varies teacher to teacher.

Regarding the second research question, the necessity of the training in acting in voice education has been disclosed according to the experiences and of the participants.

The findings of the third research question indicated that the basic requirements of an opera singer should also be qualified as an actor/actress.

Discussion and Conclusion: In general, the methodology of Mihail Chekhov was accepted as the main theoretical educational methodology in acting in the present study, and the findings were compared with the methodology by Chekhov. The results of the comparison revealed that Chekhov's methodology could be the theoritical basis for training in stageacting in the voice education. 


\title{
Oyunculuk Eğitimi Metodolojisinin Şan Eğitiminde Kullanılması: Mihail Çehov Sistemi*
}

\begin{abstract}
Salim SEVER ${ }^{* *}$
ÖZ. $\mathrm{Bu}$ araştırmada, oyunculuk eğitimi metodolojisinin şan eğitiminde kullanılmasına ilişkin olarak, (1) şancı eğitimine genel yaklaşım, (2) Profesyonel Şancıların, Opera Sanatçısının Oyunculuğuna İlișkin Deneyim ve Görüşleri, ve (3) Sancı ve Eğitimci Kișiliği ile Tanınan Uzman Kișilerin, Kendi Alanları ve Şancı Eğitiminin Bir Öğesi Olarak Oyunculuk Sanatına Bakışları olmak üzere üç alt probleme cevap aranmıştır. Sahne ve oyunculuk eğitiminin müzik eğitimi bölümlerinde yapılmadığı, konservatuarlarda ise sistematik bir yaklaşımdan çok, dersi veren kișiye bağlı bir işlenişin olduğu ortaya çımıştır. Yaşanılan deneyimlerden yola çıkılarak mesleki ihtiyaçlar konusunda alınan bilgilerden hareketle, şan eğitimi sürecinde oyunculuk eğitiminin gerekliliği ortaya konulmuştur. Sahneye çıkan kişide bulunması gereken özellikler araştırılmış ve şancının aynı zamanda oyuncu da olması gerektiği ortaya konulmuştur. Oyunculuk eğitimi konusunda Mihail Çehov'un oyunculuk eğitimi yöntemi kuramsal temel olarak belirlenmiş, şancının eğitimi sürecinde oyunculuk derslerine kuramsal temel olabileceği belirtilmiştir.
\end{abstract}

Anahtar Sözcükler: Şan, Oyunculuk, Mihail Çehov

\footnotetext{
Bu makale Feridun Büyükaksoy danışmanlığında gerçekleştirilen ve Abant İzzet Baysal Üniversitesi Sosyal Bilimler Enstitüsünce kabul edilen "Oyunculuk Eğitimi Metodolojisinin Şan Eğitiminde Kullanılması" adlı doktora tezinin ilgili bölümlerinden üretilmiștir.

* Öğretim Görevlisi Dr. Ankara Üniversitesi Eğitim Bilimleri Fakültesi, İlköğretim Bölümü.

E-posta: salimsvr@gmail.com
} 


\section{GİRIŞ}

Müzik ve tiyatronun kökleri ilkel ritüel ve seremonilerdir. Ses ve ritim, seremonileştirme süreçlerinin doğal unsurlarıdır. $\mathrm{Bu}$ süreçler içerisinde insanın fiziksel ve duygusal durumu değişime uğramakta, yani ses ve ritmi içeren ritüel ve seremoni, insanı ortak duyumsamanın yaşandığı ve paylaşıldığ farklı bir algı ve davranış boyutuna taşımaktadır.

Şamanistik ritüellerde şaman öbür dünya ile iletişim kuran kişi olarak çeşitli maskeler de kullanarak şarkı söyleyip dans etmekte ve izleyici için mistik bir ortam yaratmaktadır. Şener (1993: 13)'e göre "Bu aşamada kutsal törenler içerik bakımından büyüsel, biçim bakımından dramatiktir." Storr (1993: 16-17)'a göre eski Yunan'da şarkı, dans, şiir ve ilahilerle müzik, ayrılmaz bir bütünlük oluşturmuş ve bu sebepten dolayı "müzik" ayrı bir kelime olarak kullanılmamıştır. Müzik ve tiyatro birlikteliği ile oluşan opera ve müzikaller ise müziksel-dramatik bir birlik yaratma amacinın somutlaşmış biçimleri olarak sanat içerisinde önemini korumaktadır. Kökeni itibarı ile bir arada olan müzik ve tiyatro, gerektirdiği gündelik yaşam ötesi fiziksel ve ruhsal güçle, günümüz icracısının (şanciloyuncu) sanatının gerektirdiği her konuda gelişmesini gerektirmektedir.

Şan ve oyunculuk bir arada düşünüldüğünde, şark1 söyleme sirasında oyunculuk kalitesi ve oyunculuk sırasında şarkı söyleme kalitesinin nasıl sürdürülebileceği, müziğin belirlenmiş yapısı içinde dramatik özgürlüğe nasıl ulaşılabileceği, müziğin bedensel hareketler üzerindeki etkisi, ritim ve sesin karakterin içsel yaşantısıyla bağlantılandırılması gibi pek çok unsurun gerçekleştirilmesi gerekmektedir. Yine bunlarla bağlantılı olarak, şef ve orkestra ile bağlantıyı koparmadan diğer oyuncularla etkileşimi koparmama, fiziksel ve duygusal durumu zaman içerisinde gerektiği kadar sürdürebilme, söz ve müzik tekrarlanırken dramatik durumu/duruşu koruyabilme, şarkı söylenmeden durulması gereken anlarda teatral odağı ve konsantrasyonu kaybetmeme gibi yanıtlarının oyunculuk eğitimi disiplini içerisinde aranması gereken bazı alt soru ve sorunlar da akla gelmektedir. Nutku (2002: 169)'ya göre "amatörler sahneye çıktıklarında ellerini kollarını nereye koyacaklarını bilemezler, onun için de oyunla ilgili olmayan işlevsiz hareketlere yönelirler. Hatta sahne duruşları yanlıştır, attıkları adımlar, yaptıkları hareketler yapaydır. Gövdelerinin duruşundan, ayaklarını zemine basmalarına dek bilgisizlik ve eğitimsizlikten gelen bir hantallık vardır."

Modern çağın Avrupa merkezli dünya tasavvuru sonrasında gelişen egzotik doğu ilgisi, antropoloji alanındaki çalışmalar, nesnel bilimsel araştırmalara verilen değerin sanatı bilimselleştirmesi ve psikoloji alanındaki gelişmeler doğrultusunda sanatçıların, sahne üstüne taşıyacakları insanları yeniden tanımlama arayışına girmeleri sonucu olarak "Batı tiyatro tarihinde 
ilk defa 20. Yüzyılda oyunculuk teorilerinden söz edilmeye başlanmış, somut gözlemlenebilir yöntemler oluşturulmuştur” (Karaboğa 2005: 47).

Oyuncunun imgeleminin yaratıcı gücünü ön plana çıkaran Mihail Çehov, döneminin natüralist sanat anlayışı için "sanatçı natüralist sanat eserine kendinden bir şey katamaz, görevi sadece doğayı az ya da çok kesinlikte kopyalamakla sınırlandırılmıştır" (Chekhov, 2005: 42) der. Materyalist düşüncenin imgelemi ve dolayısıyla yaratıcılığ 1 yok ettiğini, To the Actor adlı kitabında;

"Oyuncular, yaratıcı sanatçının gerçek amacının, yaşamın dış görünüşünü taklit etmek değil, onu tüm alanlartyla yorumlayarak, izleyiciyi yaşam fenomeninin yüzeysel anlamlarının ardına bakmaya itmek olduğunu, ürkütücü bir biçimde unutmaya meyilliler" (Chekhov, 1953: 3) ifadesiyle belirtmiştir.

Çehov'un oyunculuk sisteminin bütününde, oyuncunun oynayacağ 1 karakteri kendi imgeleminden yaratabilecek bilgeliğe sahip olduğu anlayışı hâkimdir. Oyuncunun ilk yükümlülüğü imgeleminde karakteri resmetmektir. Kendini karakterin yerine koymak değil, karakteri bir imge olarak hayal etmektir. Çehov tekniğinin ikinci adımı imge bir biçimde kaybedildiğinde ortaya çıkan ilham/esinlenmedir.

Çehov'un ortaya koyduğu sistem, oyuncuyu oynayacağı karakteri bütünsel olarak oluşturmaya, bir bütün olarak ele almaya yönlendirecek biçimde kurgulanmıştır. Çehov'a göre bir karakter yaratmak, bütünsel sanat fikrinin yansımasıyla oluşabilir ve bu düzeye ise ancak oyuncu "Ne" sorusunun içeriğini "Nasıl" sorusu ile destekleyip bu doğrultuda çalışınca ulaş1labilir (Chekhov, 1953: 169).

Sistemin basamakları olan imgelem, konsantrasyon ve istem çalışmaları, oyuncuyu, yazarın fikrine çabucak adapte olup yaratıcı jestler oluşturmaya ve bu sayede özgün bir üslup geliştirmeye iter. Amaç oyun, oyunculuk ve üslubu bütünlük oluşturacak biçimde sentezlemektir. Eğer "üslubun ruhu sanatçının ruhunda yaşamıyorsa kostüm, dekor ve makyaj belli bir üsluba ait olsa da bunlar oyunun üslubunu oluşturmaz" (Çehov 1953: 170). Sistemde, zihin - beden ilişkisinin ölçülü bir biçimde geliştirilerek, oyunun temel fikrinin ruhsal/duyuşsal ve bedensel yönleriyle kavranabilmesi hedeflenmektedir. Oyuncu, karakteri oluştururken, psikolojik olarak imge, atmosfer, istem ve tempoyu; fiziksel olarak ise psikolojik jest, karakterin merkezi, aksesuar ve üslup özgürlüğünü kullanır. Ruhsal/duyuşsal ve fiziksel öğeler birbirine bağlıdır ve karşılıklı olarak zekâ ve imgelemin gücüne dayanırlar. Realist/ natüralist yaklaşımda karakterin fiziksel yaşamı oyuncu çalıştıkça yavaş yavaş oluşur. Çehov için ise fiziksel yaşam analiz yerine esinlenme ve seçime bağlı olarak derhal oluşmalıdır. Çehov tekniğinde karakterin tüm enerji ve hareketlerinin odağı, karakterin 
merkezidir. Oyuncu, kendisininkinden farklı olan bir karakter merkezi seçerek yürüyen, oturan, hareket eden, beslenen fiziksel karakteri yaratmaya başlar. Karakterin merkezi süreçte değişebilir ama oyuncu bir seçim yaparak başlar.

Çehov, duygusal bellek konusunda oyunculuk açısından doğru olanın gerçek bir kişiyi değil (kişinin kendi dedesinin ölümü) bir model (arketip) olarak tüm dedeleri alması olduğunu belirtir. Realist/ natüralist yaklaşımların aksine Çehov sisteminde asla duygusal bir hale girmek için oyuncu gerçek bir kişiyi model almaz.

Çehov sistemi sezgisel esinlenmeye önem verir. Psikolojik jest, sezgisel esini ve oyuncunun karakteri nasıl gördüğünü daima hatırlatacak bir imge bulutuna geçiş kapısıdır ve sahnede çok az icra edilir.

Çehov'un çok aşamalı oyunculuk sistemi tıpkı birbirine dayalı inşaat blokları gibi sistematik bir yapıdır. Derinlemesine analiz düzeyinde olmamak kaydıyla, karakterin psikolojik olarak yaratılması sürecinde birbirlerini etkileyecek ve destekleyecek düzeye gelene kadar çalışılması gereken ögeler olarak şunları belirtir:

1 - Metin

2- Karakterin metindeki his ve duyguları

3- Karakterin amacı ( Metindeki hisler ile birlikte)

4- Karakterin belirsizlik (fiziksel değişim) boyutu (dış görünüş) (disguises)

5- Çeşitli atmosferler

6- Sanatçının karaktere karşı tutumu.

Çehov'un yaratıcılık anlayışı, akıl ve bilginin sanatsal formla birleşerek imgelemden her yönüyle beslendiği bir süreç olarak formüle edilebilir. $\mathrm{Bu}$ öğeler bir araya geldiğinde, oyuncu çok katmanlı karakter yaratabilme yetisine kavuşacak ve bu sayede her türlü yüzeysel, soğuk ve salt bilimsel tümden gelimci nedenselliğin etkisinden kurtulabilecektir.

Tıpk1 diğer 20.yy sanatsal formları gibi bu sistemde de sürekli bir değişim, gelişim ve bunu sağlayacak bir dizi imge ve fikirselldüşünsel uyanışın, sanatçının imgeleminin derinliklerinde ortaya çıkması öngörülmektedir. Çehov 19.yüzyılın salt bilimsel düşünce odaklı yöntemselliğini (realizm, natüralizm) tekrar biçimlendirip imgelem, farklı bilinç katmanları ve bütünlük yaratma amaçlı sanatsal farkındalık gibi 20.yüzyıl kavramları ile kendi yöntemi içerisinde sentezlemiştir.

Sanata tüm iç ve diş dinamikleri ile birlikte bütüncül bir yapı olarak yaklaşmakta olan ve oyunculuk eğitimi sistemini de imgesel bütünlük ve buna bağlı çalışmalar üzerine kurmuş olan Mihail Çehov'un oyunculuk eğitimi sistemi bütünlüklü şancıloyuncu yetiştirmeye dönük ögeleri içermektedir. 


\section{Araştırmanın Amacı}

$\mathrm{Bu}$ araştırmanın amac1; lisans düzeyinde profesyonel müzik eğitimi verilen kurumlardaki ana dal şan öğrencilerinin eğitiminde oyunculuk eğitimi metodolojisinin kullanılma durumlarını alan uzmanı kişilerden toplanan verilerle belirleyerek, Mihail Çehov'un oyunculuk sisteminin bütünlüklü sanatçı yaratmada kullanılabileceğini ortaya koymaktır. Araştırmada aşağıdaki sorulara yanıt aranacaktır:

1. Lisans Düzeyinde eğitim veren müzik okullarında ana dal şan öğrencilerinin eğitimine genel yaklaşım nasıldır?

2. Profesyonel şancıların, opera sanatçısının oyunculuğuna ilişkin deneyim ve görüşleri nelerdir?

3. Şancı ve eğitimci kişiliği ile tanınan uzman kişilerin, kendi alanları ve ana dal şan eğitiminin bir öğesi olarak oyunculuk sanatına bakışları nasildır?

\section{Önem}

$\mathrm{Bu}$ çalışmanın ana dal şan öğrencilerinin tek yanlı eğitim sürecini bütünsel sanat anlayışıyla yeniden kurgulama gerekliliğini ortaya koyması açısından önemli olduğu düşünülmektedir.

$\mathrm{Bu}$ konu hem üretilen sanatın daha nitelikli hale gelmesi hem de yerel ve uluslararası çalışma koşullarının rekabetçi koşulları altında kendine yer bulabilecek şancı/oyuncular yetiştirmek bağlamında önem arz etmektedir.

\section{YÖNTEM}

Araştırma nitel araştırma yaklaşımıyla temel araştırma türünde açımlayıcı modelde (Karasar: 24-25) betimsel yöntemle yapılmıştır. Veriler araştırmacı tarafından hazırlanan yarı yapılandırılmış görüşme formu aracılığıyla derinlemesine görüşme sürecinde yapılan ses kaydı deşifre edilerek toplanmıştır. Elde edilen veriler betimsel ve içerik analizine tabi tutulmuştur.

\section{Araştırma Alanı}

$\mathrm{Bu}$ araştırma, Ankara, Bilkent ve Hacettepe Üniversitelerinde ve Ankara Devlet Opera ve Balesinde çalışan sanatçı ve eğitimcilerle yapılmıştır. Araştırmada şan ve sahne sanatları alanında uzman öğretim üyeleri ve sanatçılardan görüşme yoluyla veriler elde edilmiştir. 


\section{Örneklem}

Araştırmada Amaçlı (Kasıtlı) Örnekleme yöntemlerinden kartopu (zincir) örnekleme yöntemi kullanılmıştır.

Nitel araştırmada örneklem seçerken araştırma kaynaklarının sınırlılı̆̆ 1 ve kullanılan bilgi toplama yöntemlerinin özelliği nedeniyle çok sayıda birey örneklem grubu içine alınamamaktadır. Bazı çalışmalarda bir birey bile tek başına bir örneklem oluşturabilmektedir.

\begin{tabular}{|c|c|c|c|}
\hline Rumuz & Çalıştığı Kurum & $\begin{array}{l}\text { Çalısmama } \\
\text { Süresi }\end{array}$ & iş̧i \\
\hline Ezgi Tarhan & Devlet opera ve balesi & $25 \mathrm{y} 1 \mathrm{l}$ & Solist sanatçı \\
\hline Elvan Fatsalı & Devlet opera ve balesi & $20 \mathrm{yil}$ & Solist sanatçı \\
\hline Şakir Tarhan & Devlet opera ve balesi, Ank.U.Devlet Konsevatuarı & $25 \mathrm{yil}$ & Solist sanatçı, Șan Pedagogu \\
\hline Asaf Uzun & Devlet opera ve balesi, Anadolu.U.Devlet Konsevatuan & $26 \mathrm{yil}$ & Solist sanatçı, Şan Pedagogu \\
\hline $\begin{array}{l}\text { Mercan } \\
\text { Gözlükçua }\end{array}$ & $\begin{array}{l}\text { Devlet opera ve balesi, Ank.U.Devlet Konsevatuarı, } \\
\text { Bilkent U. MSSF }\end{array}$ & $40 \mathrm{yil}$ & Solist sanatçı, Şan Pedagogu \\
\hline Orhan Gözlukç̣a & Devlet opera ve balesi, Ank.U.Devlet Konsevatuarı & $42 \mathrm{yil}$ & $\begin{array}{l}\text { Solist sanatçı, Sahne ve } \\
\text { Oyunculuk Eğiticisi }\end{array}$ \\
\hline Mehmet Avcı & Devlet opera ve balesi, H.U..Devlet Konsevatuarı & 31 yil & $\begin{array}{l}\text { Solist sanatçı, Sahne ve } \\
\text { Oyunculuk Eğiticisi }\end{array}$ \\
\hline Okşan Eroğlu & $\begin{array}{l}\text { Devlet opera ve balesi, Ank.U.Devlet Konsevatuarı, } \\
\text { Bilkent U. MSSF }\end{array}$ & 28 yil & Solist sanatçı, Șan Pedagogu \\
\hline Emine Karslıoğlu & Devlet opera ve balesi & $17 \mathrm{y} 1 \mathrm{l}$ & Solist sanatç1 \\
\hline Tunç Kazancı & Devlet opera ve balesi, Ank.U.Devlet Konsevatuarı & $25 \mathrm{yil}$ & Solist sanatçı, Șan Pedagogu \\
\hline
\end{tabular}

\section{Örneklem grubuna ilişkin profil tablosu}

$\mathrm{Bu}$ araştırmanın örneklemini Ankara, Bilkent ve Hacettepe Üniversitelerinde ve Ankara Devlet Opera ve Balesinde çalışan sanatçı ve eğitimcilerden görüşme yapmayı kabul edenler oluşturmuştur.

$\mathrm{Bu}$ araştırmada tipik durumlardan evrene genelleme yapmak yerine, alana ilişkin ortalama durumlar hakkındaki bilgi ve fikirler paylaşılmıştır.

\section{Verilerin Analizi}

Literatürde farklı veri analizi yaklaşımları bulunmakla birlikte veri analizini "Betimsel analiz" ve "içerik analizi" olarak gruplamış olan Strauss ve Corbin yaklaşımını Şimşek ve Yıldırım (2004: 171) da benimsemektedir. Veri analizi sistematik araştırma sürecidir ve görüşme kayıtlarını, alan notlarını ve diğer materyalleri düzenlemektir. "Analiz veriler ile çalışmayı, onları organize etmeyi, kullanılabilir ünitelere ayırmayı, sentezlemeyi, ilişkileri araştırmayı, onların içinden önemli olanları çıkarmayı içerir" (Bogdan ve Biklen 1992: 153).

$\mathrm{Bu}$ araştırmada veriler içerik analizi tekniği ile çözümlenmiştir. İçerik analizinde temel amaç, toplanan verileri açılayabilecek kavramlara ve ilişkilere ulaşmaktır. $\mathrm{Bu}$ amaçla "toplanan verilerin önce kavramsallaştırılması, daha sonra da ortaya çıkan kavramlara göre mantıklı 
bir biçimde organize edilmesi ve buna göre veriyi açıklayan temaların saptanması gerekmektedir"( Şimşek ve Yıldırım 2004: 174-175).

İçerik analizinde veriler dört aşamada analiz edilmektedir ( Şimşek ve Y1ldirim 2004: 176-187).

1- Verilerin kodlanmasi

2- Temalarin bulunmasi

3- Verilerin kodlara ve temalara göre organize edilmesi ve tanımlanması

4- Bulguların yorumlanması

$\mathrm{Bu}$ araştırmada ses kaydı yapılarak toplanmış olan veriler yazıya dökülmüş, kavramsallaştırılarak, kodlanmış, daha sonra kodlar kendi aralarında organize edilerek temalara dönüştürülmüş ve yorumlanmıştır.

\section{Geçerlik ve Güvenirlik}

$\mathrm{Bu}$ çalışmada, iç geçerlik için a-bulguların kendi içindeki tutarlılı̆̆ 1 ve anlamlı bir bütün oluşturmalarına, b-görüşmelerin teyp kaydı ve kısa notlar tutularak farklı veri toplama ve analiz yöntemlerine açık olmasına özen gösterilmiştir.

$\mathrm{Bu}$ çalışmada, dış geçerlik için bulguların başka araştırmalarda denenebilmesi için gerekli açıklamaların yapılmasına özen gösterilmiştir.

$\mathrm{Bu}$ çalışmada, iç ve dış güvenirlik için a- araştırmanın yöntem ve aşamalarının açık ve ayrıntılı bir biçimde tanımlanmasına, b- sonuçların ortaya konulmuş olan verilerle ilişkilendirilmesine, c- farklı görüş ve açıklamaların dikkate alınmasına özen gösterilmiştir.

Araştırmanın sonunda güvenirlikle ilgili olarak, görüşme yapılan kişilerin tekrar ulaşılabilenlerinden bir kez daha randevu talep edilmiş, olumlu yanıt veren bir görüşmeciye bulgular ve yorum kısmı ile ilgili bilgi verilmiş, yorumlara katılıp katılmadığı sorulmuştur. Görüşmeci, bulgular ve yorum kısmında belirtilen görüşlere katıldığını belirtmiştir.

\section{Etik İlkeler}

1. Bu çalışmada görüşülen kişilerin isimleri saklı tutulmuş, yerine ad ve soyadlarının baş harfleri ile başlayan rumuzlar kullanılmıştır.

2. Veriler, araştırmacı tarafından deşifre edilmiş ve saklanmıştır. $\mathrm{Bu}$ işlemler için yardımcı eleman kullanılmamıştır.

Görüşme sürecinde, görüşmeye katılan kişilerin rahat olmaları ve doğru yanıtları tereddüt etmeden verebilmeleri için 1 . ve 2 . maddelerde belirtilmiş olan hususlar açıklanmıştır. 


\section{BULGULAR VE YORUM}

Uzman kişilerle yapılan görüşmeler sonucunda alınan yanıtlar incelenerek aynı veya yakın anlama gelen ifadeler kategorize edilmiş ve örüntü biçiminde ortaya konmuştur.

Birinci Araştırma Sorusuna İlişkin Bulgular ve Yorum

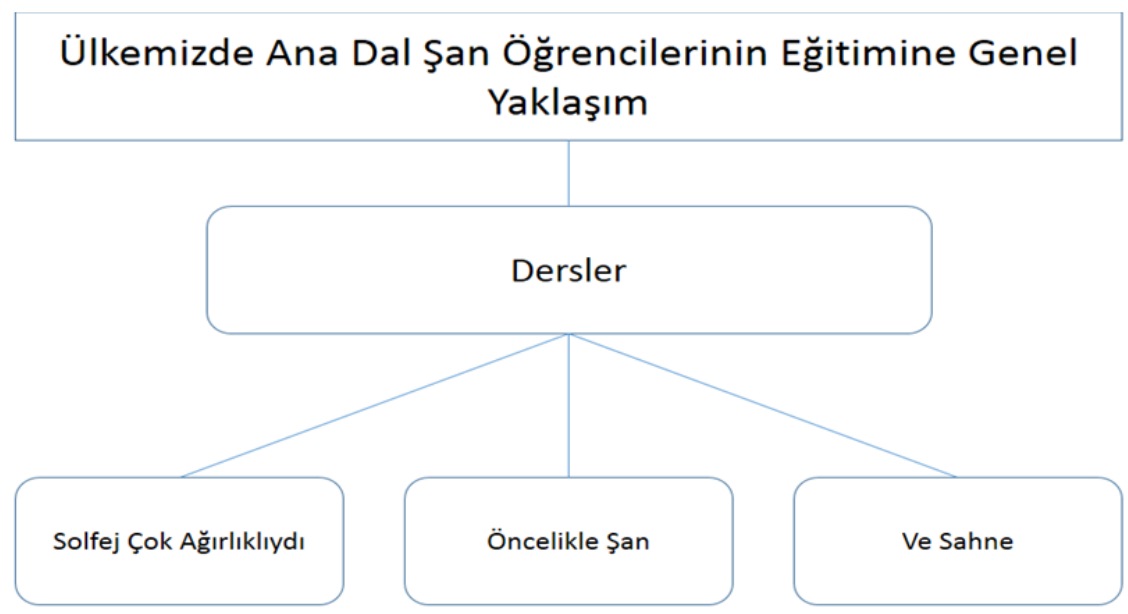

$\mathrm{Bu}$ çalışmada cevap aranan araştırma sorularından ilki "Ülkemizde Şancı Eğitimine Genel Yaklaşım Nasıldır?" sorusuydu. Verilen bilgiler doğrultusunda, ülkemizde şancı eğitimine genel yaklaşımın "dersler" ana teması altında yoğunlaştığı görülmektedir.

\section{Dersler}

Eğitim sürecinde üzerinde en çok durulan konulara ilişkin görüşler bu kod üzerinde yoğunlaşmıştır. A- Solfej çok ağırlıklıydı, B- Öncelikle şan, CVe sahne olmak üzere, üç alt tema üzerinde sıklıkla durulduğu görülmüştür.

\section{"Solfej çok ağırlıklıydı"}

E.T: Başta solfejdi tabii ki. Solfej olmadan yani nota bilgisi olmadan bu eğitimi yapamazsiniz.

M.G: Solfej çok ağırlkkliydl... Hatta Saygun'un kulağı meşhur absolut, çocuğum çeyrek koma detone oldun veya sürtone söylüyorsun vs. derdi. Böyle apır bir eğitimden geçtik biz, enstrümanlarla birlikte solfej yaptık.

T.K: Solfej en a $\breve{g} ı r d l$

Diğer görüşmeciler de solfej dersini önem verilen dersler arasında saymışlardır. 


\section{“Öncelikle San”}

Ş.T: Öncelikle şandl. Doğru ses, doğru nefes, doğru teknik.

E.T: Opera bölümü olduğumuz için şan eğitimi çok önemliydi

T.K: Opera anlamında şan vardı sadece

M.G: Tabii ki şan ă̆ırlıklı

M.A: Dur ve şarkı söyle!

E.F: Tabii ki şan

E.K: Opera ile ilişkili olarak sadece şan dersi ve içerisinde de teknik ve repertuar ağırlıklıydı diyebilirim

\section{"Ve Sahne..."}

Araştırma kapsamında görüşülen kişilerden A.U. üzerinde en çok durulan konular ders başlıkları olarak "Şan, solfej ve sahne" biçiminde siraladıktan sonra,

A.U: Sahne dersimize Necdet Aydın bey girerdi. Yoğun ve iyi çallşmalarımız oldu. Tiyatrodan bir hocamız daha vardı Erol Bey. Ondan da çok şey kazandık. Erol Bey öncelikle bize Stanislavski kitaplartnı okuttu. O kitaplardan, oynadığımız karakterin içine bürünme ve özellikle de kontrollü bürünme, yani kendini kaybetmeden, gözyaşlarına boğulmadan kontrollü bir şekilde o karakteri yansitma, hem senin karakterin, hem oynadığın karakter birlikte bir bütünlük oluşturma açısından ...onları ögrretti hoca

M.G: Sahne, önce mimik rol olarak başladl, sonra sahneye dönüştü. Tiyatro bölümüyle birlikte o derslere girer ve aynı eğitimi alırdık. Şimdi nasıldır bilmiyorum.

E.F: Sahne dersleri tabii ki çok önemliydi, dans, sahne hareketleri, yani sadece şey değil: diyelim ki nasll oturuyorsun, kalkiyorsun, elini nasll veriyorsun gibi ayrı bir şey vardl ve çok önemliydi, sonra aktörlük tekniği o da vardı. Zaten bizim Stanislavski tekniği onu çalıştık.

Bulgular 1şığında solfej ve şan derslerine önem verildiği ve işlenişinde belli bir sistematiğin bulunduğu ancak, konservatuarlarda sahne dersi bulunması ve önemsenir görünmesine karşın, belli bir sistematik yaklaşımın bulunmadığ 1 , daha çok dersi yürüten kişiye bağlı bir işlenişin hâkim olduğu söylenebilir.

\section{İkinci Araştırma Sorusuna İlişsin Bulgular ve Yorum}

Bu çalışmada cevap aranan araştırma sorularından ikincisi "Profesyonel Şancıların, Opera Sanatçısının Oyunculuğuna İlişkin Deneyim ve Görüşleri Nelerdir?" sorusuydu. Yanıtlar doğrultusunda, profesyonel şancıların beden ve vokal koordinasyonu hakkındaki görüş ve deneyimleri aşağıda ve örüntü şemasında belirtilen üç ana temada toplanmıştır.

1. Mimiği Canlandıracak Olan Hayal Gücüdür, Yaratıcılık Temel Şeydir

2. Seyirci "Oyunun İçine Çekilmek İster"

3. Eğitim İhtiyacı 


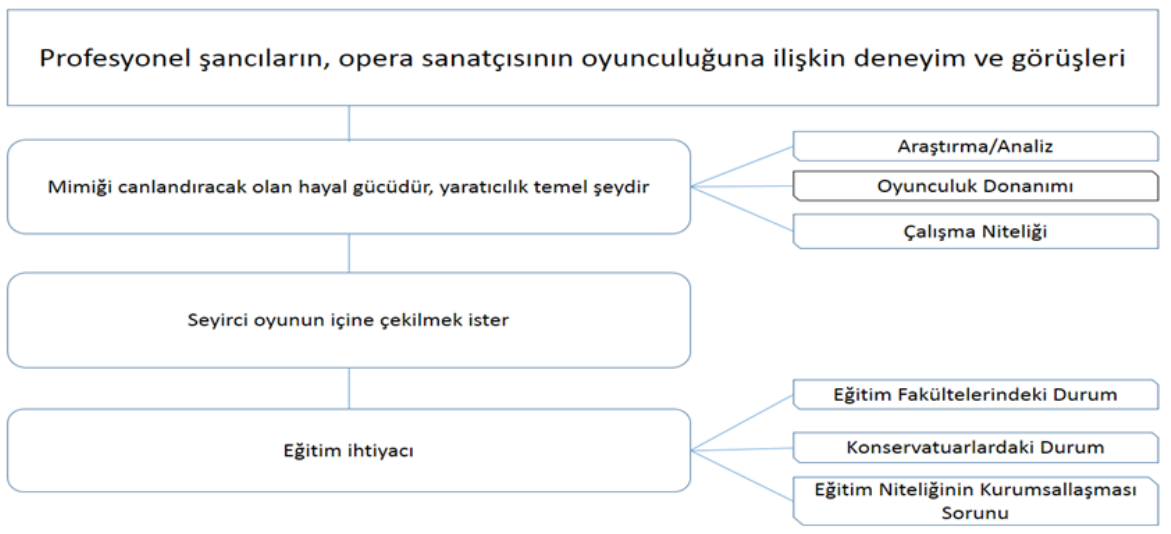

"Mimiği Canlandıracak Olan Hayal Gücüdür, Yaratıcılık Temel Şeydir"

$\mathrm{Bu}$ tema ile ilgili verilen yanıtlar; A. Araştırma $\backslash$ analiz, B. Oyunculuk donanımı, C. Çalışma niteliği olmak üzere üç tema altında toplanmıştır.

\section{Araştırma \Analiz}

A.U: Illk önce çok derinlemesine bir araştırma yapmak gerekir. Ben Ankara operasında Don Carlo söyledim. Yer çok önemli, kaç yaşında olduğu, karakter güzel mi çirkin mi, bunların araşttrmasin yaptıktan sonra rejisör size veriyor. Onun üzerine siz verilen karakteri, kostüm ve makyajın yardımıyla o şekilde ortaya koymaya çalışıyorsunuz. Bu, işin tiyatral yönü. Müzikal yönü de apayr. Don Carlo'nun nasıl bir ses gerektirdiği, nassl söylenmesi gerektiği... Çünkü her bestecinin ayrı bir yorumu vardır. Verdi başka, Puccini başka, Mozart başka bir şekilde yorumlanır. Eserin hangi devir için yazıldığının bilinmesi, bestecinin özellikle eseri yazarken hangi ruh halinde olduğunun, neler düşündüğünün bir araştırmasını yapmak lazım. Sadece eseri yorumlamak yetmiyor.

Ş.T: Esere çalışırken, karakter tahlili yaparı biz. Nasıl bir tip, o tipi bilmek lazım, oyundaki diğer karakterlerle iletişimi vs... yani sahneye çıkarken, kendi kişiliğinizden slyrllip, o karakterin içine girip oynamalısınız

T.K: Öncelikle rolü çok iyi etüt etmek gerekir

M.G: Önce karakterle iliş̧ki kurma yoluna gidiyoruz. Bunun için araş̧tırıp okuyoruz.

M.A: Iyi araştırırım, kim bu, hangi devirde yaşamış, rahatken ya da bakarken aklindan neler geçirir. İyi hâkim olmak sonrada "ben olsam nasıl yapardım sorusu"

E.T: Öncelikle karakteri, nasıl bir rol oynadı̆̆ınızı çok iyi özümsemek lazım

E.K: Öncelikle ne oynadı̆̆ınızı, nasıl bir karakter ortaya çıkarmanız gerektiğini iyi bilmelisiniz. 
Araştırma kapsamında görüşülen kişiler verdikleri yanıtlarda, rolün tam anlaşılabilmesi için yazar, dönem ve eserin yazılış koşulları hakkında derinlemesine bir araştırma yapılması ve daha sonra bunun üzerinde müzikal olarak da çalışılarak rolün yaratılmasının gerekliliği üzerinde durmuşlardır.

\section{Oyunculuk Donanımı}

Araştırma kapsamında görüşülen kişiler verdikleri yanıtlarda şanciloyuncunun özellikle oyunculuğun ve oyunculuk donanımına sahip olmanın önemini belirtmişler, bundan profesyonel yaşam öncesindeki eğitim sürecinde büyük ölçüde kazanılmasılhalledilmesi gereken bir olgu olarak bahsetmişlerdir.

E.T: Altyap şart. Altyapısız olmaz...Bir altyapıyla gelmişle dişardan gelmiş bir insan arasinda mutlaka fark oluyor.

A.U: Rejisör size bir takım şeyler gösterebilir mimik olarak, o karaktere uygun olman için ama senin hayal gücün ve yaratıcılı̆̆ı yoksa o ezberlediğin mimik ve hareketler boş ve anlamsı olur. O mimiği canlandıracak olan senin hayal gücündür. Yaraticllik temel şeydir.

...Stanislavski kitaplarını okuttu. O kitaplardan, oynadı̆̆ımız karakterin içine bürünme ve özellikle de kontrollü bürünme, yani kendini kaybetmeden, gözyaşlarına boğulmadan kontrollü bir şekilde o karakteri yansitma, hem senin karakterin, hem oynadığın karakter birlikte bir bütünlük oluşturma açısından.

M.A: Tv de görüyoruz evladinı kaybetmiş bir anne... feryat var ama cümleler karışık, bizde tüm mesele o feryadı cümleleri karlştırmadan bir araya getirebilmek. Burada yine başa dönüyoruz tabii; eğitim!”, ... süreç içinde aktörün ne yaptı̆̆ı önemli; işte aktörlük burada başliyor. Bunun da başlangıcl konservatuarlar

E.F: ...sahne dersleri tabii ki çok önemliydi, sonra aktörlük tekniği vardl. Zaten bizimki Stanislavski tekniği onu çalıştık.

O.G: ... \%70 sanaţ̧ının kendi üretimi, \%30 rejisördür. Iyi bir sanaţ̧ her zaman rejisörün dediğini anında yapar. Duygu atmosferini iyi bir sanatçı yaratir.

Bulgular 1şı̆̆ında vokal teknikle ilgili zorluklar nedeniyle oyunculuk konusu üzerinde öğrencilerce çok durulmadığı, bununla birlikte profesyonel hayatta oyunculuk donanımına olan ihtiyacın fark edildiği, yaratıcılik ve hayal gücünün şancıloyuncu için gerekli olduğu ancak pratikte çok kullanılamadığı, bunun sebebinin ise eğitim sürecindeki eksiklikler olduğu söylenebilir.

\section{Çalışma Niteliği}

Araştırma kapsamında görüşülen kişiler verdikleri yanıtlarda şanciloyuncunun seslendirilen eserin/rolün oyunculuk yönüne mutlaka çalışması gerektiğini belirtmişlerdir. 
Araştırma kapsamında görüşülen kişiler verdikleri yanıtlarda ayrıca şancıloyuncunun yapay, bayağı ve klişelerden arınmış bir karakter ortaya koyması gerektiğini belirtmişlerdir.

Araştırma kapsamında görüşülen kişiler verdikleri yanıtlarda şancıloyuncunun rolüne teatral olarak çalışmasının gereğini belirttikten sonra, bu çalışmanın alt yapısının eğitim süreci içerisinde hazırlanmış olması gerektiği üzerinde önemle durmuşlardır.

E.T: Evde de bazı şeyleri tekrarlamak çalışmak gerekiyor... sahneleri mutlaka çalışmak gerekiyor.

A.U: Yapaylaştıracak zorlamalardan kaçınmak gerek her zaman

M.A: Ali baba ve kirk haramiler de bacaksız diye bir rol oynuyordum, eserin başında bacağını kesiyorlar ve bu bacağımı belime bağlayıp bir buçuk saat oynadım. Bunun için çalışmam gerekti uzun süre bacağımı bağlayarak gezdim ve çalıştım. $O$ da bir eğitim süreci ve yeri burası (okul).

Ş.T: Söylerken ağzınızdan çıkan cümleyi vücudunuzun oynaması lazım. Bu bir. Bundan daha zoru var; partneriniz söylerken onun rolünü oynamak. Onun ağzından çıkanı, sizin seyirciye vermeniz çok önemlidir bana göre.

O.E: Bir duygunun yüzlerce ifade şekli vardır. Ancak bizler, bizden çok uzaktaki insana da derdimizi anlatmak zorunda olduğumuz için, daha büyük oynamak zorundayız. Ben şimdi sizinle konuşurken yaptığım mimiği sahnede kullanamam, bunu için bir çalışma gerek. Klişe ve sahtelikten uzak durarak bunu çallşmak ve yapmak şart, yoksa ya çok komik duruma düşersiniz ya da az kalırsiniz sahnede.

Bulgular 1şı ğında sahnede var olabilmek için duruş, jest ve mimik çalışılması ve bunların hayal gücü ile birleştirilmesi gerektiği, sahnede bütünü yansitan bir oyuncu duruşunun olması gerektiği, bu duruşun bayağılaştırıcı klişelerden arındırılmış olması gerektiği ve tüm bu gerekliliklerin alt yapısının eğitim süreci içinde edinilmiş olması gerektiği söylenebilir.

\section{Seyirci "Oyunun İçine Çekilmek İster"}

Araştırma kapsamında görüşülen kişiler verdikleri yanıtlarda şancıloyuncunun, seyirciyi oyunun içine çekebilmesi için oynadığ 1 karakterle görsel ve duygusal olarak bütünleşmiş olması gerektiğini belirtmişlerdir.

A.U: Yeni gelmiş bir insan olaya daha çok sinema gibi bakar. Oyuncuların karakterlere fiziksel olarak uygun olup olmadiklarina dikkat ederler

Ş.T: Seyirci bizden öncelikle bir görsel güzellik bekler. Sahnede güzel durmak lazım. Ondan sonra da güzel şarkı, güzel oyun vs... Operaya gelip güzel bir akşam geçirmek istiyorlar. İyi oynayan, güzel söyleyen insanlar görmek isterler.

O.E: Bizden en çok beklenen şey; sahnemizle, rolü üzerimize giymemizle, şarkıcılı̆̆ımızla, gelen seyircilerin hiçbirini dışarıda bırakmadan, oyunun içine 
çekebilmek, bu konsantrasyonu sağlayabilmek. Çünkü seyirci oyunun içine çekilmek ister.

M.G: Seyirci tabii ki rolü gerçekleştirmenizi, söylemenizi ve oynamanızı bekler.

T.K: Öncelikle ses özelliklerini ortaya koymayl ve tabii ki rolle beraber bütünleşmesini bekler. Komple o role uygunluk bekler

E.F: Benim için önemli olan rolü herkese sevdirmek, o rolü çok iyi bir şekilde anlatmak. $O$ duyguları hissettirmek, onu da yapmak için tabii ki hem şancl, hem aktör olman gerekiyor.

Araştırma kapsamında görüşülen kişiler sahneden indiklerinde seyirciyi yakalama başarısını gösterebilmiş, şancı ve oyuncular olarak hatırlanmak istediklerini belirtmişlerdir. Bununla ilgili olarak

E.T: Herkes çok iyi hatırlanmak ister. Çok başarılı oldu, çok güzel yorumladı. Vokal ve teknik anlamda da teatral anlamda da insanların aklinda tabii ki çok iyi şekilde kalmak isterim.

A.U: Ama sonuçta bizim yapmak istediğimiz o eserin havasını aktarabilmek, onu canlandırabilmek, doğru bir biçimde eserin sonunda tabii ki o havayı yaşamış, tatmış, o psikolojide ayrlmaları bizi tatmin eder.

Ş.T: Bir bütün olarak bakmak zorundayız çünkü opera sadece ses demek değildir. Tabî ki birinci şart ses ama bana göre 1. şart ikiye bölünmüs durumda yani hem görsel hem ses olarak.

O.E: Ben her zaman şancinın bir sahne sanatçlsı olarak seyirciyi avucuna alabilmesi ve böyle hatırlanabilmesini isterim, böyle hattrlanabiliyor isem, kendimi mutlu hissederim o temsilden sonra.

O.G: Bunların tümünü söyletmek en iyisi, sahnesi iyiydi, sesi iyiydi, oyunu iyiydi, bizi etkiledi dedirtmek en iyisi, yani her açıdan.

E.F: Özellikle rolden bahsedersek benim için önemli olan seyircinin içinde o duyguların kalmasını istiyorum, yani, her zaman sesimi değil de yaşadıklarımı, olayl, duygulart hatılasinlar istiyorum.

E.K: Beğenilmek ve hem sesim, hem de oyunculuğumla akılda kalmak isterim.

T.K: Rolün gereğini yaparak iyi biçimde hatırlanmak isterim tabii.

Bulgular 1şı̆̆ğnda seyirciyi oyunun içine çekmenin bir gereklilik olduğu, başarının ve seyirci tarafından hatırlanmanın ön koşulunun seyirciyi sahnedeki duygusal atmosfere sokmak olduğu, bunun için şancıloyuncunun rolü ile görsel ve duygusal olarak bütünleşmiş olması gerektiği söylenebilir.

\section{Eğitim İhtiyacı}

Bu tema ile ilgili verilen yanıtlar, A- Eğitim Fakültelerindeki Durum, B- Konservatuarlardaki durum, C- Eğitim Niteliğinin Kurumsallaşması Sorunu, D- Profesyonel Hayatta Eğitim İhtiyacı olmak üzere dört alt tema altında toplanmıştır. Okulda alınan lalınmayan eğitim, buna ilişkin durum tespitleri ve eleştiriler biçiminde ortaya çıkmıştır. 


\section{Eğitim Fakültelerindeki Durum}

Araştırma kapsamında görüşülen kişilerden eğitim fakültesi mezunu olanlar, sahne ve oyunculukla ilgili bir eğitim almadıklarını ve çeşitli biçimlerde bunun eksikliğini gördüklerini belirtmişlerdir.

E.K: Müzik eğitimi bölümü olmasindan dolayı meslek ve eğitim dersleri vardl. Opera ile ilişsili olarak sadece șan dersi ve içerisinde de teknik ve repertuar ăğrlıklıydl. Sahne eğitimi almadı̆̆ımı için mutlaka sahnede eksikliklerimiz oluyor. Ë̆itim çok önemli.

T.K: Gazi de şan derslerinde genelde vokal tekniği üzerine Operadan Fevziye Bartu ile çalıştım. Opera anlamında şan vardı sadece.

Bulgular 1şığında eğitim fakültelerinde sahne ve oyunculukla ilgili bir ders bulunmadığı ancak görüşülen uzman kişilerin bunun eğitim sürecindeki bir eksiklik olduğunun bilincinde olduğu, salt vokal tekniğin geliştirilmesine yönelik çalışmaların yeterli olmadığı, dolayısı ile bu eksiliğin giderilmesi yolunda adımlar atılması gerektiği söylenebilir.

\section{Konservatuarlardaki durum}

Araştırma kapsamında görüşülen kişilerden konservatuar mezunu olanlar ise eğitimin durumu sahne ve oyunculuk derslerinin içeriği ve bu derslerin içerik ve işlenişine ilişkin eleştirel değerlendirmelerde bulunmuşlardır.

O.E: Maalesef bizim konservatuarlarımızda işletme fakültelerinden farklı geliştirilmemek tedir çocuklar, bu yüzden sadece "şancl" olarak kalmaktadır.

...Standart bir opera sanatçıllğg sahne dersinin yaninda, tiyatrocuların aldiğ kadar ciddi bir mimik ve rol eğitimine ihtiyacımız olduğunu düşünüyorum. Herkes kendi tecrübe ve birikimlerini çalıştırıp bu karakteri ortaya çıkarmaya çalsşlyor, ancak bu ne kadar o kişiliği yansittyor soru işareti.

M.A: Bu bir eğitim süreci aslında, bunun ta başına dönmek lazım. Yani öyle bir eğitilmeli ki insan, teksti alıp incelediğinde o kişiye adapte olabilsin. Okul süreci bu, yani aktörün ya da aktristin yapmast gereken bir şey bu, başka yolu yok. Eğitim bu başka yolu yok!

Okullarda yapılmayan da bu. Çocukların hayal gücüne önem verilmiyor, rejisör ki otur der, oturursunuz, sola git der gidersiniz, ama bu oturduğunuz ve sola gittiğiniz süreç içinde aktörün ne yaptı̆̆ önemli; işte aktörlük burada başliyor. Bunun da başlangıcı konservatuarlar; iyi bir şan eğitimi (belki) ama şan ağırlıkl çalışıldĭğ için bunlar olmuyor. Dolayıslyla hayal gücü olmayan da sanatçı olamaz, bunun da binlerce çalıştırma yöntemi var, tiyatrodan koptuğumuz için bunlar yürümüyor.

Bulgular 1şı̆̆ında konservatuarlarda öğrencilerin bazı bireysel çabaların etkili olduğu kısa dönemler dışında, genel anlamda tek taraflı ve dengesiz bir eğitim süreci sonunda sadece "şancı" olabildikleri, sanatla ilgili diğer kısımların ve özellikle de oyunculuğun bireysel yeteneğin ötesine geçemediği, bunun 
sanatsal düzeyi düşürdüğü, temsilleri müsamereye ve klişelere indirgediği, bunun tiyatrodan kopuşun bir sonucu olduğu ve çözümünün oyunculuk eğitiminin okula girişten itibaren çok ciddi bir biçimde verilmesi ile mümkün olabileceği söylenebilir.

\section{Eğitim Niteliğinin Kurumsallaşması Sorunu}

Görüşülen uzman kişiler, eğitimde bireysel çabaların bireyin mesleki ömrü ile sınırlı olduğunu belirterek, ekolleşme anlamında bir kurumsallassmaya ihtiyaç olduğu yönünde görüş bildirmişlerdir.

M.G: Insanlar kendi gayretleriyle bir yere varabiliyorlar veya varamiyorlar. Daima dışarıya bağımlı kalmışız...Çok iyi sesler olmasına rağmen okullardaki ĕgitimler mi yetersiz kallyor yoksa sanatçılar mı fazla önemsemiyor eğitimi, opera sanatında bir geriye gidiş, bir çöküş var, dekadans gibi.

M.A: Bence sahne bir. Şekspir bir tane. Birlikte olabilmeleri için 1. sinıftan itibaren tiyatro ögrrencilerine şan, şancllara da tiyatro dersleri vermeye basslarsinız olur, bunun temeli budur. Ben konservatuarda bunu elimden geldiğince yapmaya çalışlyorum, ama bu benim sistemim. Yani yarı buradan gidersem birisinin daha buna devam etmesi lazım

Bulgular 1şığında sahne ve oyunculuk derslerinin işlenişinin öğretmenin bireysel tutumuna ve mesleki ömrüne bağlı olduğu, bu durumun daha sistematik bir biçimde, programlı bir anlayışla ele alınması gerektiği, vokal performansa iliş̧in gelişme olmasına karşın bunun opera sanatındaki geriye gidişi durduramadığ 1 , eğitim niteliğinin kurumsallaşmasının, bahsedilen olumsuzlukların giderilmesinde gereklilik olduğu söylenebilir.

\section{Üçüncü Alt Probleme İlişkin Bulgular ve Yorum}

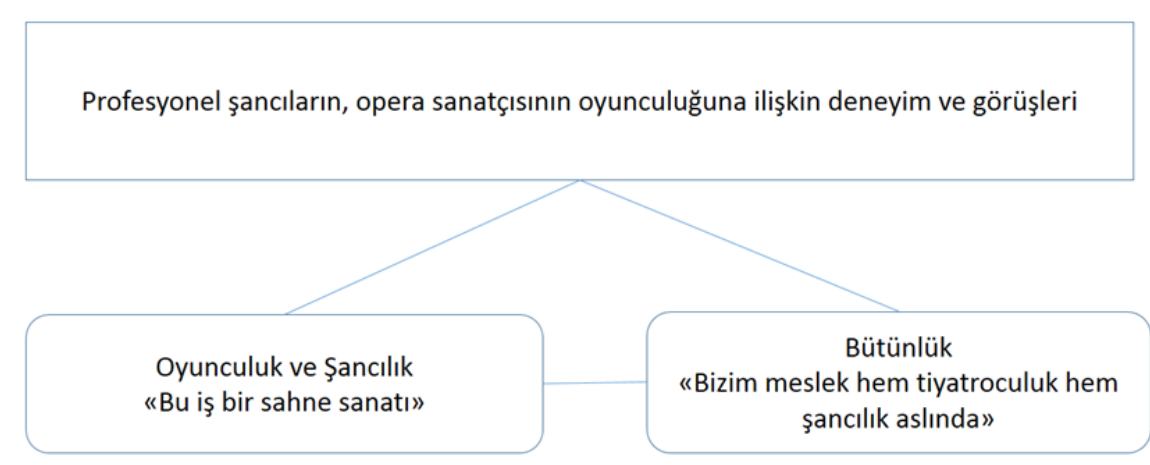

Görüşülen uzman kişilerin verdikleri yanıtlar doğrultusunda, oyunculuk sanatına bakışları, örüntü şemasından da anlaşılacağ 1 gibi A. "Bu iş bir sahne sanatı", B. "Bizim meslek hem tiyatroculuk, hem şarkıcılık aslında olmak üzere iki tema altında yoğunlaşmıştır. 


\section{Oyunculuk ve Șancılık "Bu iş bir sahne sanatı"}

Araştırma kapsamında görüşülen kişiler, şancılık ve oyunculuğun birbirinden ayrı düşünülmemesi gereken iki öğe olduğunu, bunun sanatsal bütünlüğün ortaya çıkarılması açısından çok önemli olduğunu hatta sadece "aktör" kelimesinin bile yeterli olacağını belirtmişler, oyunculuk ve şancılığın bir arada olmasının zevkle izlemeyi de beraberinde getirdiğini vurgulamışlardır.

E.T: Sahnede çıkıp sadece şarkı söylemek değil opera. Ayrıca o teatral yeteneği de ortaya çlkarmak gerekiyor... Temsillere gelirseniz fark edersiniz; Bir şancılar var, birde şancı oyuncular. Şarkı söylüyorsunuz ama onu bir de oyunculuğunuzla yansitmanı gerek.

O.E: Bu iş bir sahne sanatl, dolayıslyla bir opera şarkacısının tabii ki aktörlaktris olması şarttır...Aynı cümle içinde kullanılması gereken bu iki kelimeye o kadar az rastllyoruz ki böyle bir soru sormaya itmiş sizi. Aslında bu hakikaten tek kelime bence. Tek bir anlam, tek bir ifade, olması gereken şey budur.

M.A: Yan yana kullanulmasa, sadece aktör dense daha mutlu olurum. Bunlar bir çünkü... Komple olabilmek için özellikle ABD de böyle, dans edeceksiniz, iyi aktör ya da aktris olacaksınız, herhangi bir enstrümana iyi derecede hakim olacaksıniz. Her şeyle ilgisi olan insandır aktör.

M.G: Şancının harika bir oyunculuk tekniğine sahip olması gerekir. Oyunculuk içten gelen bir şey, ama eğitimin de katkisı büyük.

O.G: Durup da söylemek değil, bütünleşmek lazım, iyi oynamak lazım. Olmazsa olmazlardan ikisi de.

E.F: Benim tercihim şancı aktör, yani ikisi bir arada. Sadece şark söylemekten ben de zevk almiyorum, canlandırmak benim için de çok önemli.

E.K: ... Şancı aynı zamanda aktördür benim için. Salt şancı diye bir şey yoktur, baştan sona donanım ve bir sanatçı bütünlüğ̈̈ yaratmak gerekir. Ayrı ayrı değildir bunlar.

A.U: Gerçekten iyi bir aktör olup, gerçekten iyi bir şancı olan dünyada çok az kişi var. Tabii ki çok zevkle izlediğimiz sanatçılar bunlar.

\section{Bütünlük "Bizim meslek hem tiyatroculuk hem şarkıcılık aslında"}

Araştırma kapsamında görüşülen kişiler sanatsal bütünlüğün olabilmesi için sanatçının şancılık ve oyunculuğunun birlikte var olması gerektiğini, bunun tersinin tat vermediğini ve opera sanatına ilginin azalma nedenlerinden birinin de bu durum olduğunu belirtmişlerdir.

O.E: Bizim meslek hem tiyatroculuk hem şancllık aslinda. Bir sanatçının şarkıcılı̆̆ ve sahnesi, yaratıcllı̆̆ mutlaka el sıkışmalıdır. İkisinden biri tökezlediği zaman saniyorum gerekli tadı vermiyor.

M.A: Niye ilgi azallyor operaya, çünkü kimseye çekici gelmiyor şu anda, niye gelmiyor? Birileri bağırlyor bağırlyor gidiyor çünkü. Ĕger böyle bir şey 
olsaydl açardim teybimi, hiç gitmeye zahmet etmeden en kral seslerden dinler uyurdum yani. Oranin bir heyecanı var ki... Eskiden müthiş bir dekor ve kostümler vardl. İnanlmaz, şaşaalı. Bu kostüm ve dekor oyunculuk gerektirmiyordu, bir taraftan göz oyalaniyor, bir taraftan da dinliyorsunuz. Ama şimdi her şey minimale döndü, ışık sanatı daha çok ortaya çıktı, o zaman ne oldu; aktörlük! Mecbursun. Işık, müzik, pano ve siz. Şimdi öyle yapamazsinız artik, duramazsinız!

M.G: Seni sürüklemeli, Oyunun içine sokmal, hem oyunculuk yanıyla, hem de sesiyle, hem tekniğiyle... Birinden biri eksik olursa ben tat almam. Eskiden opera demek ses demektir diye bir imaj vardl, şimdi buna katılmiyorum açıkçası. Birinden biri eksik olursa olmaz.

\section{SONUC}

Konservatuar ve müzik okullarında müziğe ilişkin solfej ve ana çalgı olarak şan gibi temel dersler belirli bir sistematik anlayışla gerçekleştirilmektedir. Eğitim ve Güzel Sanatlar Fakültelerine bağlı müzik okullarında oyunculuğa ilişkin dersler bulunmamaktadır. Konservatuarlarda ise oyunculuk konusunu parçalı olarak ele alan "Sahne", "Hareket", "Mimik ve Rol" adlarıyla açılmış dersler bulunmakta ancak dersi veren kişinin seçimleri ve ders verme süresine bağlı olarak şanc1/oyuncu bütünleşmesini gerçekleştirecek ortam oluşamamaktadır. Görüşülen uzmanlarca vurgulanan "hayal gücü”, "yaratıcılık”, "seyirci oyunun içine çekilmek ister", “ bu iş bir sahne sanatı", "bizim meslek hem tiyatroculuk hem şancılık aslında" biçimindeki temalar sorunları ve çözüm önerilerini içermekte ve Çehov sistemiyle de örtüşmektedir. Uzmanlarca özet olarak vurgulanan husus ise salt şancıdan, bütün halinde bir şancı/oyuncuya dönüşümün sanatsal ve mesleki bir gereklilik olduğudur.

Şarkı söyleme ve rol yapma konusunu birlikte ele alan yurt dışında yayımlanmış kitaplar da bulunmaktadır (Burgess\&Skilbeck, 1999; Clark, 2002; Craig, 1990; Hong Young, 2003; Melton\& McGregor, 2007; Ostwald, 2005). Bu kitaplarda da konu belli başı basit hareketlerle belirli anlamları ifade etme çalışmaları, müzik eşliğinde hareket edebilme çalışmaları, temel jest ve mimik kullanımı gibi yüzeysel çalışmalar biçiminde ele alınmaktadır.

Müzik ve drama, bir performans içerisinde ne düzeyde bulunurlarsa bulunsunlar, kaçınılmaz bir biçimde birbirlerini etkilemektedirler. Sahnedeki unsurları açımlayan dramatik eylem, eylemi tanımlayan ve destekleyen metin ve eylem ile metni kendi diliyle yorumlayıp aktaran müzik bir bütünlük oluşturmaktadır. Bundan dolayı, şarkı söyleme biçimi değiştiğinde drama da değişmekte, aynı şekilde oyunculuktaki değişim de şarkı söylemeyi farklılaştırmaktadır. Müziğin daha hızlı ya da daha yavaş 
çalınması veya bir puan d'org, dramatik akış üzerinde önemli bir değişim yaratmaktadir.

Müzikal ifade; ritim, armoni, renk, ses gürlüğü ve bunların metne uygulanması ile oluşturulan gerilim ve çözülümlerle yaratılmaktadır. Dramatik ifade araçları olan eylem ve söz ise müzikal ifade gibi bölümlendirilebilir değildir. Bundan dolayı müzik, dramayı tanımlamakta, en azından dramaya zaman çatısı sağlamaktadır. Öte yandan drama da müziği, karakterleri, durumları ve mekânlarıyla, hikâyenin gerçek dünyasına taşımaktadır.

Şanciloyuncu, kendisi dışında biri olarak, librettoda ve müzikte öngörülen karakteri ortaya çıkarıp, müzik-drama ilişkisini canlandıran bir yapısal öğe olarak bu noktada karşımıza çıkmaktadır. Bu aynı zamanda teatral gerçeklik, insanın güzellik ve kusurları ile müziğin deneyüstü mükemmelliği arasında bir köprü kurma eylemidir. Müzikle drama arasındaki bu ilişki, müziksiz metin ve eylemle, metin ve eylemsiz müzik aralığında değişebilmektedir. Şancıloyuncu bunları birbirinden ayırdığında, sanatın bütünüyle bağlantı kurma gücünü yitirerek, sanatsal ifadenin güvenilirliğini azaltmış olacaktır. Buradan hareketle denilebilir ki, bütünlüklü bir algılama, bütünlüklü sanat yapmanın ön koşuludur.

Bu noktada, sanata tüm iç ve diş dinamikleri ile birlikte bütüncül bir yap1 olarak yaklaşmakta olan ve oyunculuk eğitimi sistemini de imgesel bütünlük ve buna bağlı çalışmalar üzerine kurmuş olan Çehov'un oyunculuk eğitimi sistemi, salt şancıdan, şancıloyuncu yetiştirmeye dönüşmesi gereken eğitim sistemimiz içinde yer alabilecek niteliklere sahiptir.

Oyunculuk sanatının gizemi, "beden”, "ses”, “duygu” gibi bölümlere ayrılarak da anlaşılmaya çalışılabilir. Ancak bunları birbirinden bağımsız olarak düşünmek Çehov (1953: 24)'a göre "vücudumuzla sadece fiziksel olarak çalışmaktır; bulacağımız şey, [sadece] duygularımızın olduğu odada bulunduğumuzu fark etmek olacaktır". Bu öğelerden biri üzerinde diğerlerinden bağımsız olarak çalışmak, insan doğasının bir gereği olarak mümkün olamamaktadır. Ancak, bunların birbirleriyle ilişkili olarak ayrı ayrı çalışılması halinde aynen alfabedeki harfler gibi A,B,C... tanınıp kaotik olmayan kombinasyonlar üretilebilir (Çehov 1953: 24).

Librettistin sözleri ve bestecinin müziği, şancı olmaksızın sadece kâğıttaki bazı simgeler olarak kalmakta, opera sanatı şancının özgün yorumu olmadan cansız ve izleyiciden uzak bir etkinliğe, bir tür kostümlü şarkıcılığa dönüşmektedir. Her şancının kaçınılmaz bir biçimde aktör de olduğunu anlattı̆g kitabında Daniel Helfgot (2003: ix), aldıkları eğitim sayesinde rol yapmaksızın sadece şarkı söylemenin yeterli olduğunu düşünen şancılardan "onlar sahnede oynamayı pasta süsü gibi görmektedirler" biçiminde bahsetmektedir. 
Şanc1/oyuncu, rolünü daha etkili bir biçimde ortaya koyabilmek için, benliğinin derinliklerine dalıp özgün bir karakter çıkarmalıdır. Çehov'un, oyunculuğun süreğen olması gerektiğine ilişkin görüşü bu noktada önem kazanmaktadır. Böylece eserdeki dramatik örgü birbirine bağlanabilir; aralarında köprüler kurulabilir. Örneğin, şancıloyuncunun önce birine sarılıp sevgisini göstermesi, sonra da onu öldürmesi gerekiyorsa, sadece anlık oynayan şanciloyuncu, bu iki eylem durumu arasındaki psikolojik ve fiziksel geçişi de o derece kopuk ve uyumsuz yapacaktır.

Opera librettoları çoğu zaman olay örgüsündeki pek çok detayı atlayarak ilerlemektedir. Böyle durumlarda müzik, psikolojik geçişin bağlanmasına yardımcı olurken, oyuncu/şancı da bu geçişi koparmadan sürdürmek ve genişletmek için karakterin içsel yolculuğunu etkili bir şekilde sunmalıdır ki, bunun koşulu şancı/oyuncu olabilmiş olmaktır.

Çehov, sahne üzerinde gündelik hayatın yeniden üretiminin sadece ucuz taklitten ibaret bir durum yaratacağını ve sanatçıdan çok, fotoğrafçıya benzeyeceğini belirterek, sanatın gündelik yaşamdan fazlası olduğunu vurgulamıştır. Bu görüşten hareketle, karakteri yaratabilen oyuncu şancı hem kendisiyle, hem de seyirciyle eseri gerçekten buluşturmuş olacaktır. Oyunculuk eğitimi almamış şancıdan rol yapmasını istemek, şan eğitiminden geçmemiş tiyatro oyuncusundan arya söylemesini istemek gibi bir duruma tekabül etmektedir.

Şancı için ses eğitimi kadar gerekli olan oyunculuk eğitiminin şansa bağlı bir olgu olarak bırakılmaması, şancının oyunculuğunun ham yetenek düzeyinde kalmaması gerektiği uzman görüssleri ile ortaya konulmuştur. Yine uzmanlarca yapılan "yaratıcılık" ve "bütünlük" gibi vurgular aynı zamanda Çehov sisteminin de çıkış noktası olarak şancı/oyuncuyu var edip opera sanatının gereklerinin karşılanması konusunda uygun bir rehber olabilecek niteliktedir.

\section{KAYNAKLAR}

Bogdan, R.C. Biklen S.K. (1992). Qualititive Research for Education: An Introduction to Theory and Methods, Boston: Allyn and Bacon.

Carlson, R. (2013). What Do I Do With My Hands?: A Guide to Acting for the Singer, Las Vegas, Personal Dynamics Publishing.

Chekhov, M. (1985) Lessons for the Professional Actor, D.H. du Prey (Ed), New York, Performing Arts Journal Publications.

Chekhov, M. (1953). To the Actor; On the Technique of Acting, NewYork, Harper and Row.

Chekhov, M. (2005). The path of the actor/ A. Kirillov, B.Merlin (Eds), New York, Routhlege.

Clark, M.R. (2002). Singing, Acting And Movement In Opera, Bloomington, Indiana University Press. 
Craig, D. (1990). On Singing Onstage, New York, Applause Theater Publishers.

Helfgot, D., Beeman, W.O. (1993). The Third Line, USA, Shirmer Books.

Hong-Young, A. (2003). Singing Professionally, Revised Edition: Studying Singing for Actors and Singers

Karasar, N. (1994). Bilimsel Araştırma Yöntemi: Kavramlar, ilkeler, Teknikler, Ankara, 3A Araştırma Eğitim Danışmanlık Ltd.

Kayes, G., (2005). Singing and the Actor, New York, Routledge.

Mallet Burgess, T.D., Skilbeck, N. (1999). The Singing and Acting Handbook: Games and Exercises for the Performer, London, Routledge.

Melton, J., McGregor, A. (2007). Singing in Musical Theater: The Training of Singers and Actors, New York, Allworth Press.

Nutku, Ö. (2002). Sahne Bilgisi, İstanbul, Kabalc1 Yayınevi.

Ostwald, D. (2005). Acting for Singers: Creating Believable Singing Characters, New York, Oxford University Press.

Storr, A. (1993). Music and the Mind, New York, First Ballantine Books.

Şener, S. (1993). Oyundan Düşünceye, Ankara, Gündoğan Yayınları.

Wettig, K. (2012) Singing like Callas and Caruso: Belcanto Voice and Body Training

Yıldırım, A., Şimşek H. (2004). Sosyal Bilimlerde Nitel Araştırma Yöntemleri, Ankara, Seçkin Yayınevi. 